\title{
A Study on the Effects of Leadership Style, Compensation, and Physical Work Environment on High School Economics Teachers in Subang Regency
}

\author{
Edi Sugiono ${ }^{1}$ \\ DOI: $10.35445 /$ alishlah.v13i3.1439
}

\begin{abstract}
Article Info
Abstract

Keywords:

Leadership Style;

Compensation;

Physical Work

Environment;

Teacher Work

Motivation

Motivation for Instructors at work is an incentive to move the spirit of teachers in such a way that their conduct can be oriented toward genuine attempts to attain the goals that have been established. As a result, the purpose of this study is to examine whether the leadership style, salary, and physical work environment of high school Economics instructors in Subang Regency have an impact on their work motivation. The sampling technique utilized in this study was a saturated sample technique, which meant that all members of the population were sampled, with a total of 221 teachers. Based on the findings of a multiple linear regression analysis performed with the SPSS 21 software package. This study's findings indicate a positive and statistically significant relationship between leadership style, remuneration, and physical work environment and the job motivation of high school Economics teachers in Subang Regency.
\end{abstract}

Kata kunci:

Gaya Kepemimpinan;

Kompensasi;

Lingkungan Kerja Fisik;

Motivasi Kerja Guru

\begin{abstract}
Abstrak
Motivasi guru dalam bekerja merupakan dorongan untuk menggerakkan semangat guru sedemikian rupa sehingga perilakunya dapat berorientasi pada upaya yang sungguh-sungguh untuk mencapai tujuan yang telah ditetapkan. Oleh karena itu, tujuan dari penelitian ini adalah untuk menguji apakah gaya kepemimpinan, gaji, dan lingkungan kerja fisik pengajar Ekonomi SMA di Kabupaten Subang berpengaruh terhadap motivasi kerja mereka. Teknik pengambilan sampel yang digunakan dalam penelitian ini adalah teknik sampel jenuh, artinya seluruh anggota populasi dijadikan sampel, dengan jumlah guru sebanyak 221 orang. Berdasarkan temuan analisis regresi linier berganda yang dilakukan dengan paket perangkat lunak SPSS 21. Temuan penelitian ini menunjukkan bahwa terdapat hubungan yang positif dan signifikan secara statistik antara gaya kepemimpinan, remunerasi, dan lingkungan kerja fisik dengan motivasi kerja guru Ekonomi SMA di Kabupaten Subang.
\end{abstract}

\section{INTRODUCTION}

An increasing rate of globalization necessitates a country's ability to produce skilled workers. Every facet of a country's development benefits from having highly qualified human resources. Every country strives to improve the quality of its human resources, particularly in education, through the application of scientific knowledge, technological innovation, and a positive mental attitude

\footnotetext{
${ }^{1}$ Universitas Nasional, Jakarta, Indonesia

Email: edisugiono33@yahoo.com
}

Vol.13 (3) December, 2021

Received: November 28, 2021; Received in revised form: December 19, 2021; Accepted: December 27, 2021; Available online: December 30, 2021. This is an open access article under a Creative Commons Attribution-NonCommercial-ShareAlike 4.0 International License. 
(Nagggala, 2020). Education is a critical component in the development of well-rounded individuals who excel academically as well as morally. In order to achieve national development goals, quality educational institutions must produce high-quality human resources that can be mobilized (Sudarsana, 2016).

According to Daryanto (2013), one of the most critical aspects of education is the teacher's role and function. Students' success is inextricably linked to the teacher's effectiveness who teaches them. One of the most important aspects of a teacher's job is his or her ability to assess the quality and quantity of the work they produce in the course of performing the duties assigned to them. No teaching or learning can occur without teachers, so they are a necessary component of the educational process (Erwinsyah, 2017). Teachers play an essential role in the educational process. Still, it is not uncommon to find them carrying out their duties with a lack of enthusiasm, resulting in a lack of progress toward the desired outcomes. Many factors have contributed to this: the dearth of enthusiasm among teachers for their jobs (Balqis et al., 2014).

A teacher's demeanour can tell you a lot about a student's work motivation. Change in energy from within the person can be seen as a change in feelings and an immediate response to an existing goal, which can be seen as motivation (Sugiono \& Rachmawati, 2019). Motivation can also be defined as a force that propels people to take action in pursuit of their goals. Motivation refers to symptoms that involve an act of encouragement towards specific goals (Ardiana, 2017). Suppose this is associated with the encouragement of each person in carrying out their activities. In that case, the goals to be achieved cannot be separated from the concept of what the leader wants. That is why motivation is a concept that can be used when moving individuals to start and behave directly, following what the leader wants (Harefa, 2020).

Concerning the principal's leadership who wants to move the teacher to do his job, he must motivate the teacher to focus all his energy and attention to achieve the results that have been set (Sugiono \& Pratista, 2019). The role of the principal is very much needed in efforts to improve the quality of teaching. Mulyasa (2013) argues that effective principal leadership can empower educators, education staff, and other school members to realize quality, smooth, and productive learning processes. The principal is the party most responsible for unifying the existing subsystems, creating harmony in them, and pushing effectively towards the vision set previously. Sutrisno (2012) stated that, in general, the principal's leadership involves three kinds of leadership styles, namely autocratic style, democratic style, and laissez-faire style. The autocratic style is a leadership style in which all decisions are absolutely in the leader's hands. The leader dictates the tasks that his subordinates must do. The leader judges the associates subjectively. The leader takes all steps of the organization himself so that the organization's future becomes uncertain (Gumilar, 2014).

Improving the quality of teacher work needs to pay attention to the welfare of teachers. Teacher welfare can be realized through appropriate or appropriate salaries, compensation, bonuses, and health insurance. This needs to be given to motivate teachers to work even more challenging (Pianda, 2018). A person's motivation can be developed by themselves or by several external parties, which primarily revolves around monetary rewards and non-monetary tips, which can impact their overall performance, according to Winardi (2001). Depending on the circumstances, it can either be positive or negative. Compensation is one of the motivators that drives a teacher's work. The compensation in question is compensation for the achievements that have been achieved by a teacher based on work experience that will provide inner satisfaction in the form of material, money, bonuses, or in-kind (Ardian, 2019). While remuneration can guarantee minimum physical fulfilment is one of the absolute requirements to expect good work. An increase in salaries for teachers is now necessary because the task of teachers is getting tougher. On the other hand, a high salary can motivate a teacher to work even more challenging (Sugiono \& Efendi, 2020).

A work environment is a place where employees perform activities every day. Researchers have conducted some previous research. Sutrisno (2012) explains that a workplace's overall facilities and infrastructure, including the workplace, facilities, cleanliness, lighting, tranquillity, and even the 
working relationship between the people in the workplace, can all affect work implementation. Sedarmayanti (2011) explains that the work environment is divided into two, namely the physical and non-physical environment, to increase workers' enthusiasm. The physical work environment in schools is about lighting, air temperature, humidity, noise, and work safety. At the same time, the non-physical environment is all conditions related to work relationships. Wibowo (2014) states that work relations include human relations within the organization, both between superiors and subordinates and among co-workers. The creation of good cooperation, good relations between managers and associates, the image of the organization in the eyes of the community is good; it will create a good work environment and play a role in the spirit and motivation of teachers. Unlike previous studies, this study aims to examine whether the leadership style, salary, and physical work environment of high school Economics teachers in Subang Regency affect their work motivation.

\section{METHODS}

Research is an activity carried out to obtain the truth or facts, which is carried out by collecting and analyzing data carefully, clearly, and systematically, and can be accounted for or can be tested for truth (Sugiyono, 2011). This type of research is quantitative research. The source of data used in this study is primary data, by conducting interviews, observations, and distributing questionnaires to all high school economics teachers in Subang Regency. The type of data used is ordinal data. The population in this study were all high school economics teachers in Subang Regency, as many as 221 people. The sampling technique uses a saturated sample technique, which takes all population members to be sampled. The data analysis techniques used in this study were validity and reliability tests, descriptive statistics, classical assumption tests, and multiple linear regression. Descriptive statistics used to describe the data in this study which consists of leadership style (X1), compensation (X2), physical work environment ( $\mathrm{X}_{3}$ ), and work motivation (Y).

The hypothesis is defined as a temporary answer to the problem formulation. Hypotheses based on the problems to be studied are as follows:

H1: To test this hypothesis, we looked at the effects of leadership style, salary, and the physical work environment on Subang Regency's high school economics instructors' levels of motivation.

H2: For high school economics teachers in Subang Regency, leadership style has an impact on the level of work motivation.

H3: Subang Regency high school economics instructors' job motivation is influenced by remuneration.

H4: Subang Regency high school economics instructors' job motivation is influenced by their physical work environment.

\section{FINDINGS AND DISCUSSION Descriptive Analysis}

The results of descriptive statistical calculations in this study use the variables of leadership style, compensation, work environment, and work discipline. The mean leadership style is 3.62; this shows that most respondents answered agree, which means the principal's leadership style is good. Meanwhile, the mean compensation is 3.74, which means that most of the respondents decided that the compensation provided was as expected. Furthermore, the mean work environment is 3.70, which means that most of the respondents agree that the physical work environment in schools is good. And the mean work motivation is 3.58 , which means that most of the respondents agree that work motivation is good.

\section{Classical Assumption Test}

The classical assumption test used in this study is the data normality test, multicollinearity test, heteroscedasticity test, and autocorrelation test. A data normality test was conducted to ensure that all data in this study were usually distributed. The multicollinearity test in this study used the tolerance and VIF values. The aim was to determine whether there was a powerful correlation 
between the independent variables (independent). The heteroscedasticity test is used to see whether in this study there is heteroscedasticity or not. The autocorrelation test used in this study was to determine whether there was autocorrelation or not.

Kolmogorov Smirnov test can be seen from the Asymp value. Sig is more than 0.05; based on the results of the Kolmogorov Smirnov test, the data is normally distributed. With the results of the histogram test, it can be said that the shape of a perfect bell is in the shape of a perfect bell, while in the P-P graph, the plot of the points follows a diagonal line so that the data is normally distributed. In the Kolmogorov Smirnov test the value of Asymp.Sig.(2 tailed) is 0.728. Based on the study results, it can be said that the research data has been normally distributed.

The results of the multicollinearity test in this study indicate that there is no multicollinearity, where the VIF value of the leadership style is 1.001, compensation is 1.106, and the work environment is 1.104. The results of the heteroscedasticity test in this study indicate that there is no heteroscedasticity; with the glejser test, the criterion in the glejser test is if the parameter coefficient value for the dependent variable has a sig value $>0.05$. The sig value is more than 0.05 . leadership style 0.096 , compensation sig value 0.447 , and work environment sig value 0.956 .

The autocorrelation test used in this study is by looking at the results of Durbin Watson. The results of the autocorrelation test in this study did not occur autocorrelation, namely by looking at the Durbin-Watson value between du and 4-du, so it can be concluded that there is no positive or negative autocorrelation.

\section{Multiple Linear Regression}

Regression analysis was used for hypothesis testing. The results of multiple linear regression testing are as follows.

Table 1. Multiple Linear Regression

\begin{tabular}{cccccc}
\hline \multirow{2}{*}{ Model } & \multicolumn{2}{c}{$\begin{array}{c}\text { Unstandardized } \\
\text { Coefficient }\end{array}$} & $\begin{array}{c}\text { Standardized } \\
\text { Coefficient }\end{array}$ & t & Sig. \\
\cline { 3 - 5 } & $\mathbf{b}$ & Std. error & Beta & & \\
\cline { 2 - 4 } 1. Constant & -1.042 & 2,404 & & -.424 & .654 \\
X1 & .214 & .076 & .179 & 2.567 & .010 \\
$\mathrm{X}_{2}$ & .478 & .087 & .383 & 5.278 & .000 \\
$\mathrm{X}_{3}$ & .324 & 0.93 & .229 & 3.261 & .002 \\
\hline
\end{tabular}

Based on the multiple linear regression table above, the formula for the regression model is obtained as follows:

$$
\mathrm{Y}=-\mathbf{1 . 0 4 2}+\mathbf{0 . 2 1 4 X 1}+\mathbf{0 . 4 7 8} \mathrm{X} 2+0.324 \mathrm{X}_{3}+\mathrm{e}
$$

Based on the regression coefficient $\mathrm{X} 1$, which has a positive value of 0.214 , it shows that for every increase in one unit of leadership style (X1), work motivation will increase by 0.214 . The regression coefficient $\mathrm{X} 2$ has a positive value of 0.478 , which indicates that for every increase in one unit of compensation, work motivation will increase by 0.478 . The $\mathrm{X}_{3}$ regression coefficient is positive at $\mathbf{0 . 3 2 4}$, meaning that for every one-unit increase in the physical work environment, work motivation will increase by 0.324 .

\section{1. t-test}

The t-test, also known as the partial test, is a statistical procedure that examines the relationship between each independent variable and the dependent variable. When comparing the $t$ count results to those in the $t$ table, it is important to search for any significant differences between the two.

The leadership style of High School Economics Teachers in Subang Regency affects their job motivation. It can be seen that $2,567>1,97718$, so the null hypothesis is rejected; the conclusion is that leadership style significantly affects work motivation. Compensation affects the job motivation 
of personnel in Subang Regency's high school Economics department. It can be seen that 5.278) > 1.97718, so the null hypothesis is rejected; the conclusion is that compensation has a significant effect on work motivation. The physical work environment affects the motivation of high school economics teachers in Subang Regency. It can be seen that $3.261>1.97718$, so the null hypothesis is rejected; the conclusion is that the work environment significantly affects work motivation.

2. F-test

The F test, also known as the Simultaneous Test or Model Test/Anova Test, is a type of statistical test used to determine how all independent factors influence a dependent variable. Alternatively, we can evaluate whether the regression model we develop is good/significant or not good/non-significant by comparing it to the data. It is possible to do the $\mathrm{F}$ test by comparing the calculated $\mathrm{F}$ with the $\mathrm{F}$ table; if the calculated $\mathrm{F}$ count is more than the $\mathrm{F}$ table (Ho is rejected, Ha is accepted), the model is significant, as indicated by the significance column on the ANOVA. It is also marked by the fact that the significance column (percentage) will be greater than alpha if $\mathrm{F}$ count is less than F table. And vice versa, if F count is less than F table, then the model is not substantial; it is also marked by the fact that the significance column (percentage) will be greater than alpha.

Table 2. Test f

\begin{tabular}{cccccc}
\hline Model & Sum of Square & Df & Mean Square & F & Sig \\
\hline Regression & 447.551 & 4 & 149.582 & 16.789 & $0^{0.000^{b}}$ \\
Residual & 1186.439 & 137 & 8.637 & & \\
Total & 1633.990 & 141 & & & \\
\hline
\end{tabular}

It can be seen that $16,789>2.67$, with a significant level obtained that is 0.000 less than 0.05 . So the null hypothesis is rejected; the conclusion is that leadership style, compensation, and work environment simultaneously affect work motivation.

\section{The Influence of Leadership Style on Work Motivation}

According to this study, the results of hypothesis testing show a strong correlation between leadership style and job motivation among high school economics teachers in Subang, Malaysia. This study found that the better the principal's leadership style, the more motivated the teachers are to do their best work. A competent leader can influence his subordinates and guarantee that the individuals he leads are able to perform to their fullest potential. " Reading the moods of one's coworkers and the atmosphere in which they work is an important part of being a good leader. The maturity of subordinates is a crucial factor to consider. Leadership style and the maturity level of associates are directly linked so that the leader is able to get enough compliance or influence. What kind of leadership style is needed to encourage the widest possible engagement of all subordinates? Leadership is always influenced by a variety of elements, including the personality traits of the leader, the structure of the organization, and factors outside the leader's control. Various leadership styles can emerge as a result of these diverse influences.

Pradana's (2015) on his study found that leaders have a substantial impact on staff motivation. This means that motivation will improve if a leadership style is used correctly. According to Syaidid's (2013) research, employee motivation is also positively influenced by leadership style.

\section{The Effect of Compensation on the Work Motivation}

Based on the results of hypothesis testing in this study, it can be concluded that compensation has a significant effect on the motivation of High School Economics teachers in Subang Regency. This shows that the better the school and the government balance, the more teachers' work motivation will increase. In addition to the salary given every school month, the government also provides a type of compensation in holiday allowances given once a year. With the provision of 
holiday allowances once a year, teachers will feel more prosperous, reduce anxiety, get attention, and be appreciated for the hard work expended at work. Employees will be more motivated to improve the quality of work and be more disciplined in their work. Meanwhile, there are government efforts to improve the welfare of teachers, namely through certification, although it is still not evenly distributed. Hasibuhan (2016) suggests remuneration (salary and interest) also influence employee motivation because remuneration will give employees satisfaction and love for the company/work. If they receive appropriate compensation, employees will be motivated to work diligently, calmly, and do their best for the company.

The results of this study are in line with research conducted by Budiman (2016), which found that there is an influence of compensation variables on work motivation variables for honorary teachers in the Meliau Regency. Similar to the research conducted by Yusuf \& Bolotio (2021), which states that compensation variables affect the work motivation of non-permanent teachers in Islamic Private Vocational High Schools in Manado.

\section{The Effect of the Physical Work Environment on the Work Motivation}

For high school economics instructors in the Subang area, it can be stated that their job motivation might be influenced by their work environment. These findings show that the higher the management of the work environment, the greater the teacher's work motivation. Physical and social-cultural phenomena that affect persons are referred to as the environment. People engage in work as physical and mental activity in order to achieve personal fulfilment. When it comes to their jobs, workers are affected by various factors outside of their control, including their co-workers. There is more to the environment than just a table and chairs, cupboards, and a few pieces of office machinery. Good working relationships between co-workers, subordinates, managers, systems and processes, and applicable rules all impact the workplace. In the workplace, all of these things are present. In the absence of balance, it can be stated that the work environment is a condition or condition in a work environment, both physically and psychologically, that influences the mood of people who work. This includes work facilities, comfort, connections with colleagues, and creative thinking. The findings of Warna et al. (2020) regarding the effect of work salaries, rewards, and work environment on the work motivation of Economics Teachers at senior high school are consistent with these findings. Working conditions have a considerable impact on the motivation of economics teachers.

\section{The Effect of Simultaneous Leadership Style, Compensation, and Physical Work Environment on the Work Motivation}

Teachers in the Subang district who teach economics have higher motivation levels because of the principal's leadership style, which includes encouraging morale, communicating effectively with educators, and mobilizing and directing teachers to make sacrifices to achieve the goals, according to the study. Teachers are also given non-wage compensation, such as holiday allowances and teacher certification, for a specified period to improve their well-being and the safety and comfort of their physical and non-physical work environments. In order to maintain a clean and safe work environment that includes clean restrooms, comfortable parking spaces, good working relationships between co-workers, subordinates and leaders, and following all applicable rules is an example of good workplace hygiene and good business practices. In order to ensure that instructors are happy and productive, as well as that the organization's goals are met. Having a positive work environment, leadership style, and salary contribute to teachers' job satisfaction. The educational process will be successful as a result of this. As Maria (2019) found, work motivation and transformational leadership style have a direct correlation with the physical work environment. The findings show that employees' work motivation is influenced by their leadership style and the physical environment in which they work. 


\section{CONCLUSION}

According to the study's findings, it can be stated that the leadership style of high school economics teachers in the Subang district has a limited impact on their job motivation. The principal's leadership style is seen as effective in motivating teachers and other education employees to do their best work. Work motivation is influenced by compensation in a major way, but only to a certain extent. For high school economics teachers in Subang, the more their salary, the greater their job incentive. Workplace motivation is influenced by various factors, some of which are significant. Their work might influence work motivation for high school Economics Teachers in the Subang district in a nice and safe atmosphere. Finally, leadership style, remuneration, and work environment all impact job motivation for high school economics teachers in Subang Regency at the same time, according to the findings.

\section{REFERENCES}

Ardian, N. (2019). Pengaruh Insentif Berbasis Kinerja, Motivasi Kerja, Dan Kemampuan Kerja Terhadap Prestasi Kerja Pegawai UNPAB. JEpa, 4(2), 119-132.

Ardiana, T. E. (2017). Pengaruh Motivasi Kerja Guru terhadap Kinerja Guru Akuntansi SMK Di Kota Madiun. Jurnal Akuntansi dan Pajak, $17(02)$.

Balqis, P., Ibrahim, N. U., \& Ibrahim, S. (2014). Kompetensi Pedagogik Guru Dalam Meningkatkan Motivasi Belajar Siswa Pada SMPN 3 Ingin Jaya Kabupaten Aceh Besar. Jurnal Administrasi Pendidikan: Program Pascasarjana Unsyiah, 2(1).

Daryanto. (2013). Menyusun Modul. Yogyakarta: Gava Media.

Erwinsyah, A. (2017). Manajemen Kelas Dalam Meningkatkan Efektifitas Proses Belajar Mengajar. TADBIR: Jurnal Manajemen Pendidikan Islam, 5(2), 87-105.

Gie, T. L. (2009). Administrasi Perkantoran Modern. Yogyakarta: Liberty.

Gumilar, E. W. (2014, September). Pengaruh Gaya Kepemimpinan Kepala Sekolah Terhadap Motivasi Kerja Guru Di Sman o1 Wungu Madiun Pada Tahun 2013. In FIPA: Forum Ilmiah Pendidikan Akuntansi (Vol. 2, No. 2).

Harefa, D. (2020). Pengaruh Antara Motivasi Kerja Guru IPA dan Displin Dengan Prestasi Kerja. Aksara: Jurnal Ilmu Pendidikan Nonformal, 6(3), 225-240.

Hasibuan, M. (2013). Manajemen Sumber Daya Manusia Cetakan Ketujuh Belas. Jakarta: Bumi Aksara.

Mangkunegara, A. A. P. (2013). Manajemen Sumber Daya Manusia Perusahaan. Bandung: Remaja Rosdakarya.

Mulyasa, E. (2004). Manajemen Berbasis Sekolah: Konsep, Strategi dan Implementasi. Bandung: Remaja Rosdakarya.

Nanggala, A. (2020). Analisis Wacana Pembaharuan Kebijakan Zonasi Menteri Pendidikan Dan Kebudayaan Nadiem Makarim Sebagai Solusi Pemerataan Pendidikan di Indonesia. Jurnal Pendidikan Kewarganegaraan Undiksha, 8(2), 46-56.

Pianda, D. (2018). Kinerja Guru: Kompetensi Guru, Motivasi Kerja dan Kepemimpinan Kepala Sekolah. Jejak Publisher.

Priansa, D. J. (2014). Perencanaan \& Pemgembangan SDM. Bandung: Alfabeta.

Rivai, V., \& Mulyadi, D. (2003). Kepemimpinan Dan Perilaku Organisasi. Jakarta: Raja Grafindo Persada.

Sedarmayanti. (2011). Tata Kerja dan Produktivitas Kerja. Bandung: Mandar Maju.

Sudarsana, I. K. (2016). Peningkatan Mutu Pendidikan Luar Sekolah Dalam Upaya Pembangunan Sumber Daya Manusia. Jurnal Penjaminan Mutu, 1(1), 1-14.

Sugiono, E., \& Efendi, S. (2020). Leadership Style, Work Discipline, and Compensation to Employee Performance through Job Satisfaction. ENDLESS: International Journal of Future Studies, 3(2), 47-63.

Sugiono, E., \& Pratista, R. M. (2019). Pengaruh Kepemimpinan Transformasional, Motivasi dan Lingkungan Kerja Fisik terhadap Kinerja Karyawan PT Rafa Topaz Utama di Jakarta. Oikonomia: Jurnal Manajemen, 14(2).

Sugiono, E., \& Rachmawati, W. (2019). Pengaruh gaya kepemimpinan transformasional, Budaya organisasi danmotivasi ekstrinsik Terhadap kinerja karyawan PT Semen Padang, Jakarta Selatan. Oikonomia: Jurnal Manajemen, 15(1). 
Sugiyono. 2011. Metode Penelitian Kuantitatif, Kualitatif dan R \& D. Bandung: Alfabeta.

Sutrisno, E. (2012). Sumber Daya Manusia. Surabaya: Gramedia.

Trang, D. S. (2013). Gaya Kepemimpinan dan Budaya Organisasi Pengaruhnya Terhadap Kinerja Karyawan. Jurnal EMBA: Jurnal Riset Ekonomi, Manajemen, Bisnis Dan Akuntansi, 1(3). Wibowo. (2014). Manajemen Kinerja. Jakarta: Rajagrafindo Persada.

Winardi, J. (2001). Motivasi \& Pemotivasian dalam Manajemen. Jakarta: Raja Grafindo Persada. 